\title{
PERANAN DISKUSI KELOMPOK DALAM PEMBELAJARAN TEMATIK TERHADAP PERILAKU AKADEMIK SISWA DI SD NEGERI KADUAGUNG KECAMATAN SINDANGAGUNG KABUPATEN KUNINGAN
}

\author{
Ade Maharani ${ }^{1}$, Dede Darkam ${ }^{2}$ \\ Pendidikan Guru Sekolah Dasar, STKIP Muhammadiyah Kuningan \\ dededarkam@umpk.ac.id
}

\section{Info Artikel}

\section{Sejarah Artikel:}

Diterima Bulan Januari, 2020

Dipublikasikan

Bulan

Februari, 2020

Keywords:

metode diskusi

kelompok, perilaku

akademik siswa,

siswa sekolah dasar

\section{Abstrak}

Penelitian ini bertujuan untuk mengetahui perilaku akademik Siswa dalam diskusi kelompok Pembelajaran Tematik Di SD Negeri Kaduagung. Metode penelitian ini memakai metode penelitian deskriptif kualitatif. Lokasi penelitian bertempat di Sekolah Dasar Negeri Kaduagung Kecamatan Sindangagung Kabupaten Kuningan dengan subjek penelitian yaitu siswa kelas $\mathrm{V}$ yang berjumlah 38 orang siswa dan guru wali kelas $\mathrm{V}$ sebagai informan. Teknik pengumpulan data dan instrumen wawancara, observasi, dokumentasi dan angket. Berdasarkan hasil penelitian ini dapat diambil kesimpulan bahwa terdapat dampak positif dari pembelajaran diskusi kelompok terhadap perilaku akademik siswa kelas V di SD Negeri Kaduagung Kecamatan Sindangagung Kabupaten Kuningan. Guru berperan untuk meningkatkan kualitas perilaku akademik siswa dalam proses pembelajaran selama berada di sekolah. Sehingga disini guru sangat berperan dalam meningkatkan kualitas perilaku akademik siswa. Dengan demikian dapat disimpulkan bahwa Terdapat Dampak Yang Positif Dari Pembelajaran Diskusi Kelompok Terhadap Perilaku Akademik Siswa Kelas V di SD Negeri Kaduagung Kecamatan Sindangagung Kabupaten Kuningan.

\begin{abstract}
This study aims to determine academic behavior of student during the learning process of group discussion in the Implementation of Thematic Leraning in SD Negeri Kaduagung. The location of the study was at the Kaduagung Public Elementary School in Sindangagung Subdistrict, Kuningan Regency with the subject of the research being the fifth grade students totaling 38 students and the fifth grade homeroom teacher as informants. Data collection techniques and interview instruments, observatios, documentation and questionnaires. Based on the result of this study it can be concluded that there is a positive impact of group discussion learning on academic behavior of fifth grade students at SD Negeri Kaduagung, Sindangagung Subdistrict, Kuningan District. The teacher's role is to improve the quality of students academic behavior in the learning process while in shcool. So here the teacher is very instrumental in improving the quality of student academic behavior. Thus it can be concluded that there is a Positive Impact of Group Discussion Learning Against Academic Behavior of Class V Students at SD Negeri Kaduagung, Sindangagung District, Kuningan District.
\end{abstract}

Alamat Korespondensi Email

\footnotetext{
: STKIP Muhammmadiyah Kuningan : dededarkam@upmk.ac.id
}

(C) 2020 Ade Maharani $^{1}$, Dede Darkam ${ }^{2}$.

Under the license CC BY-SA 4.0 ISSN 2541-6855 (Online) ISSN 2541-0199 (Cetak) 


\section{Jurnal Lensa Pendas, Vol. 5 Nomor 1 Tahun 2020, HIm 41 - 47}

Ade Maharani ${ }^{1}$, Dede Darkam ${ }^{2}$

\section{PENDAHULUAN}

Pembelajaran tematik dalam pendidikan sekolah dasar tidak terlepas dari perkembangan akan konsep pendekatan terpadu itu sendiri. Kurikulum terpadu cenderung lebih memandang bahwa suatu pokok-pokok bahasan harus terpadu (integrated) secara menyeluruh. Keterpaduan dapat dicapai melalui pemusatan pelajaran pada suatu masalah tertentu dengan alternatif pemecahan melalui berbagai disiplin ilmu atau mata pelajaran yang diperlukan.

Berdasarkan hasil pengamatan lapangan, diperoleh bahwa metode yang sering digunakan adalah metode diskusi kelompok karena diskusi merupakan metode relevan yang digunakan dalam pembelajaran tematik yang dapat membentuk sikap pengelolaan emosional siswa. Setiap siswa memiliki cara tersendiri dalam menentukan sikap terhadap suatu permasalahan begitu pula dengan sikap dalam menghadapi globalisasi dalam lingkungan sekitar.

Diskusi sebagai suatu metode yang dapat digunakan sebagai sarana dalam membentuk perilaku siswa selama proses pembelajaran. Dalam diskusi, siswa berkelompok dengan teman sekelas dan membicarakan serta memecahkan suatu permasalahan. Diskusi dapat memicu siswa untuk dapat mengungkapkan pendapatnya terhadap suatu topik permasalahan.

Pendidikan merupakan usaha pengembangan kualitas diri manusia dalam segala aspeknya. Pendidikan sebagai aktivitas sengaja untuk mencapai tujuan dan melibatkan berbagai faktor yang saling berkaitan satu dengan yang lainnya, sehingga membentuk satu sistem yang saling mempengaruhi (Tedi Priatna :dalam Ilmu Pendidikan, 2004:27).

Secara lunguitis, sebagai kata benda, pendidikan yaitu sebuah proses perubahan sikap dan tingkah laku seseorang atau kelompok orang dalam usahanya mendewasakan manusia melalui upaya pengajaran dan latihan (W.J.S Poerwadarmita :dalam Ilmu Pendidikan, 1985:702).

Belajar merupakan suatu perubahan tingkah laku dimana perubahan itu dapat mengarah kepada tingkah laku yang lebih baik. Perubahan tingkah laku karena belajar menyangkut berbagai aspek kepribadian, baik fisik maupun psikis. Perubahan perilaku yang terjadi melalui latihan dan pengalaman dalam arti perubahan tersebut disebabkan oleh kematangan tidak dianggap sebagai hasil belajar.

Sekolah sebagai salah satu sarana sebagai penyaluran pendidikan sangat berperan dalam mewujudkan tujuan pendidikan. Dalam pendidikan formal siswa dapat menggali dan mengembangkan potensi diri yang diterapkan dalam kehidupan bermasyarakat. Dalam kegiatan belajar disekolah, siswa mengalami proses perubahan perilaku karena hasil pengalaman.

"Belajar adalah perubahan perilaku yang permanen sebagai hasil dari pengalaman". Sehingga luaran yang diharapkan dalam kegiatan belajar disekolah yaitu perubahan 


\section{Jurnal Lensa Pendas, Vol. 5 Nomor 1 Tahun 2020, HIm 41 - 47}

Ade Maharani ${ }^{1}$, Dede Darkam ${ }^{2}$

perilaku berupa kebiasaan. Selain bertugas mencerdaskan bangsa, sekolah juga memiliki tugas membentuk perilaku anak melalui pendidikan disekolah (Morgan, dalam Agus Suprijono, 2009:2).

\section{METODE PENELITIAN}

Peneliti menggunakan metode penelitian deskriptif kualitatif. Deskriptif Kualitatif ini menafsirkan dan menguraikan data yang bersangkutan dengan situasi yang sedang terjadi, sikap serta pandangan yang terjadi didalam suatu masyarakat, pertentangan antara dua keadaan atau lebih, hubungan antar variabel yang timbul, perbedaan antara fakta yang ada serta pengaruhnya terhadap suatu kondisi dan sebagainya.

Pendekatan Kualitatif adalah metode penelitian yang digunakan untuk meneliti pada kondisi objek yang alamiah dimana peneliti adalah sebagai instrument kunci, teknik pengumpulan data dilakukan secara triangulasi data, analisis data bersifat induktif dan hasil penelitian kualitatif lebih menekankan makna pada generalisasi. Peneliti ikut berpartisipasi dalam lapangan, mencatat secara hati-hati apa yang telah terjadi, melakukan analisis reflektif terhadap berbagai dokumen yang ditemukan dilapangan, dan membuat laporan penelitian secara mendetail.

Dalam penelitian ini yang diamati yaitu perilaku siswa dalam proses pembelajaran, variasi bentuk metode yang digunakan oleh guru dalam diskusi kelompok, dan dampak dari diskusi kelompok terhadap perilaku akademik siswa kelas V.

Dengan digunakan metode kualitatif, maka data yang didapat akan lebih lengkap, lebih mendalam, kredible dan bermakna sehingga tujuan penelitian dapat dicapai. Proses pemerolehan informasi dan data dilakukan secara berulang-ulang dengan berbagai cara dan berbagai sumber.

\section{HASIL PENELITIAN DAN PEMBAHASAN}

Penelitian ini dilakukan di SD Negeri Kaduagung Kecamatan Sindangagung Kabupaten Kuningan. Pembelajaran di SD Negeri Kaduagung Kecamatan Sindangagung Kabupaten Kuningan khususnya pada kelas V sudah menerapkan Kurikulum 2013 (kurtilas), Dalam penyampaian proses pembelajaran di kelas V ini, guru menggunakan metode pembelajaran tematik sebagai pengantar pembelajaran. Pembelajaran tematik merupakan proses pembelajaran yang menggunakan tema untuk mengkaitkan beberapa mata pelajaran sehingga dapat membuat peserta didik merasakan pembelajaran yang lebih bermakna. Cara penentuan tema dalam proses pembelajaran di kelas V SD Negeri Kaduagung Kecamatan Sindangagung Kabupaten Kuningan ditentukan sesuai dengan kerikulum dan mengikuti atas dasar KI, KD dan Indikator yang akan digunakan sehingga bahan acuan mengajar yaitu rencana kegiatan pembelajaran (RPP) selama guru menyampaikan materi dalam pembelajaran. data dari hasil penelitian mengenai permasalahan yang telah 


\section{Jurnal Lensa Pendas, Vol. 5 Nomor 1 Tahun 2020, HIm 41 - 47}

Ade Maharani ${ }^{1}$, Dede Darkam ${ }^{2}$

dirumuskan, yaitu mengenai Peranan Diskusi Kelompok Dalam Pembelajaran Tematik Terhadap Perilaku Akademik Siswa Di SD Negeri Kaduagung Kecamatan Sindangagung Kabupaten Kuningan.

Hasil penelitian ini diperoleh dengan teknik wawancara dengan informan sebagai bentuk pencarian data dan dokumentasi langsung dilapangan, observasi dan pengisian angket. Penelitian ini terfokus pada perilaku akademik pada proses pembelajaran diskusi kelompok siswa kelas $\mathrm{V}$, untuk teknik pengumpulan data penelitian yaitu: wawancara kepada wali kelas V, wawancara kepada salah satu siswa yang memiliki perilaku akademik yang cukup baik dan salah satu siswa yan2 memiliki perilaku akademik yang kurang baik, wawancara dilakukan untuk mengumpulkan data mengenai perilaku akademik siswa selama proses pembelajaran diskusi kelompok, diskusi kelompok yang dapat membentuk perilaku akademik siswa yang baik dan dampak dari pembelajaran diskusi kelompok terhadap perilaku akademik siswa di kelas V. Peneliti melakukan proses observasi pengamatan kelas yaitu mengamati dan mengikuti proses pembelajaran yang sedang berlangsung di kelas V.

Peneliti melihat proses pembelajaran dari jam pelajaran pertama, kedua sampai jam pelajaran terakhir. Pada proses pembelajaran dari awal sampai akhir, peneliti melihat para siswa sangat antusias dalam melakukan proses pembelajaran yang dilakukan, guru membentuk kelompok diskusi.

Dalam pembagian kelompok satu kelompok terdiri dari 6-8 orang siswa. Dalam pembagian kelompok diskusi, guru tidak membeda-bedakan siswa satu sama lain dan cara pembentukan kelompok pun rupanya disetujui oleh para siswa.
Disini peneliti melihat setiap kelompok aktif dan ikut serta dalam menyelesaikan pokok permasalahan yang telah diberikan oleh guru. Siswa terlihat senang saat mengungkapkan pendapatnya di tempat duduk maupun di depan kelas. Masing-masing siswa terlihat sudah terbiasa dan tidak terlihat siswa yang masih malu untuk menyampaikan hasil diskusi kelompok ataupun menyampaikan hasil pemikirannya.

Tabel 4.2

Perilaku Akademik Siswa Positif dan Negatif Dalam Diskusi Kelompok

\begin{tabular}{|c|c|}
\hline Positif & Negatif \\
\hline $\begin{array}{l}\text { Semua siswa duduk di } \\
\text { bangku dengan tertib } \\
\text { pada kegiatan awal } \\
\text { diskusi kelompok }\end{array}$ & $\begin{array}{l}\text { Terdapat siswa yang } \\
\text { bercanda dengan teman } \\
\text { sekelompok. Terjadi pada } \\
\text { kelompok } 1\end{array}$ \\
\hline $\begin{array}{ll}\text { Siswa secara } & \text { aktif } \\
\text { menyampaikan } & \\
\text { pendapatnya } & \text { dalam } \\
\text { kelompok } & \end{array}$ & $\begin{array}{l}1 \text { siswa dari kelompok } 6 \\
\text { dan } 7 \text { pada diskusi } \\
\text { kelompok tidak aktif } \\
\text { dalam diskusi }\end{array}$ \\
\hline $\begin{array}{l}\text { Setiap kelompok } \\
\text { berunding membahas } \\
\text { topik diskusi dengan } \\
\text { bahasa yang baik }\end{array}$ & $\begin{array}{l}\text { Beberapa siswa berbicara } \\
\text { sendiri dengan temannya }\end{array}$ \\
\hline $\begin{array}{l}\text { Siswa dapat } \\
\text { menghargai pendapat } \\
\text { teman sekelompok }\end{array}$ & $\begin{array}{l}\text { Siswa yang duduk } \\
\text { dibelakang kurang } \\
\text { memperhatikan } \\
\text { penjelasan dari temannya }\end{array}$ \\
\hline
\end{tabular}

Tabel 4.3

Tabel Keefektifan Diskusi Kelompok

\begin{tabular}{|c|c|c|c|c|c|c|c|}
\hline NO & Kriteria & $\begin{array}{c}\text { Kel } \\
1\end{array}$ & $\begin{array}{c}\text { Kel } \\
2\end{array}$ & $\begin{array}{c}\text { Kel } \\
\mathbf{3}\end{array}$ & $\begin{array}{c}\text { Kel } \\
4\end{array}$ & $\begin{array}{c}\text { Kel } \\
5\end{array}$ & $\begin{array}{c}\text { Kel } \\
6\end{array}$ \\
\hline 1 & Semangat & 4 & 4 & 4 & 4 & 4 & 4 \\
\hline 2 & Kerjasama & 3 & 4 & 4 & 4 & 3 & 4 \\
\hline 3 & Masuk akal & 3 & 3 & 4 & 3 & 3 & 3 \\
\hline 4 & Jelas & 4 & 4 & 4 & 4 & 4 & 4 \\
\hline 5 & Relevan & 3 & 3 & 3 & 3 & 3 & 3 \\
\hline 6 & Teliti & 3 & 4 & 4 & 4 & 3 & 3 \\
\hline 7 & Mendalam & 3 & 3 & 3 & 3 & 3 & 3 \\
\hline 8 & Bahasa jelas & 4 & 4 & 4 & 4 & 4 & 4 \\
\hline 49 & Tepat & 3 & 4 & 4 & 4 & 3 & 3 \\
\hline 10 & Menarik & 4 & 4 & 4 & 4 & 4 & 4 \\
\hline $41-0$ & IotodILINH & 24 & & & 37 & 34 & 35 \\
\hline
\end{tabular}


Jurnal Lensa Pendas, Vol. 5 Nomor 1 Tahun 2020, Hlm 41 - 47

Ade Maharani ${ }^{1}$, Dede Darkam ${ }^{2}$

Berdasarkan tabel
mengenai keefektifan
kelompok dalam proses pembe
merupakan bagian dari p
akademik yang ditunjukan oleh
kelas V, tingkat keefektifan
diskusi kelompok diklasifik
dalam beberapa kategori yaitu:
Skor 40-45 = Sangat Baik
Skor 35-40 = Baik
Skor 25-30 = Cukup Baik
Skor 20-25 = Kurang

Perolehan skor dari perilaku akademik siswa dalam keefektifan diskusi kelompok berada pada kategori tingkat baik. Sehingga dapat disimpulkan bahwa perilaku akademik siswa kelas $\mathrm{V}$ yang ditunjukan melalui keefektifan dalam proses pembelajaran diskusi kelompok di SD Negeri Kaduagung merupakan diskusi kelompok yang efektif digunakan.

Pembahasan hasil penelitian ini dibagi berdasarkan tujuan dari penelitian itu sendiri. Tujuan penelitian ini adalah untuk mengetahui perilaku akademik siswa (respon), metode diskusi kelompok yang dapat membentuk perilaku akademik yang baik dan dampak dari diskusi kelompok terhadap perilaku akademik siswa kelas V di SD Negeri Kaduagung Kecamatan Sindangagung Kabupaten Kuningan.

1. Perilaku akademik siswa dalam proses diskusi kelompok dalam pembelajaran tematik di SD Negri Kaduagung.

Menurut Skinner, perilaku diartikan sebagai Reinforcement yaitu merupakan suatu konsekuensi perilaku yang memperkuat perilaku tertentu. Perilaku akademik dapat dikaitkan pula dengan respon dan reaksi terhadap stimulus yang telah diberikan. Semua warga sekolah di SD Negeri Kaduagung Kecamatan Sindangagung Kabupaten Kuningan, menunjukan perilaku yang baik, sopan santun, dari mulai memasuki gerbang sekolah. Fasilitas sekolah yang cukup baik, kondisi lingkungan yang cukup rapih, bersih dan asri. Fasilitas seperti ruang kelas dan sarana prasarana yang lainnya juga cukup memadai. Hal ini tentunya dapat mendukung dalam proses belajar mengajar, khususnya dalam sikap perilaku akademik siswa. Ibu kepala sekolah dan semua guru beserta staf TU dan tidak lupa para siswa di SD Negeri Kaduagung Kecamatan Sindangagung Kabupaten Kuningan yang menunjukan perilaku yang baik, sopan dan santun.

Hal tersebut senada dengan hasil wawancara dan observasi serta dilengkapi dengan bukti dokumentasi yang dilakukan oleh peneliti. perilaku akademik siswa selama dalam proses pembelajaran khususnya pada diskusi kelompok dalam pembelajaran tematik cukup baik

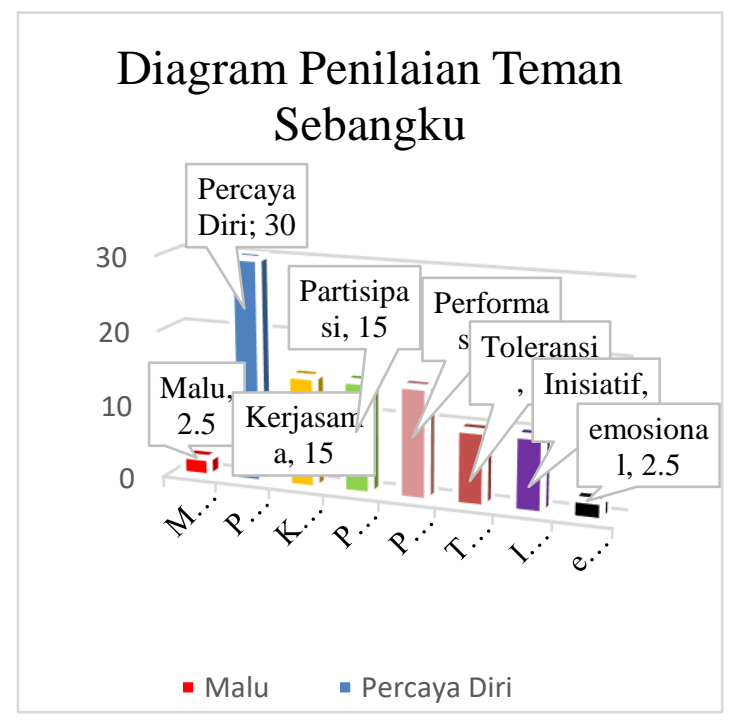

Diagram 4.1

Diagram Hasil Penilaian Teman

Deskripsi mengenai Perilaku Akademik Siswa Selama Proses Pembelajaran Tanpa Menggunakan Metode Diskusi Kelompok (Respon Siswa) Mengenai perilaku akademik 


\section{Jurnal Lensa Pendas, Vol. 5 Nomor 1 Tahun 2020, HIm 41 - 47}

Ade Maharani ${ }^{1}$, Dede Darkam ${ }^{2}$

siswa selama dalam proses pembelajaran tanpa menggunakan metode diskusi kelompok, peneliti melihat perilaku akademik yang ditunjukan oleh para siswa kelas $\mathrm{V}$ selama proses pembelajaran cukup baik.

Seperti halnya pada saat proses diskusi kelompok, pada proses pembelajaran tanpa menggunakan metode diskusi kelompok pun terdapat siswa yang bertanya mengenai apa yang guru telah jelaskan dan terdapat siswa yang berdiskusi menegnai soal yang telah guru berikan. Seperti halnya pada proses pembelajaran diskusi kelompok, pada proses pembelajaran tanpa menggunakan metode diskusi kelompok pun siswa aktif dalam proses pembelajaran.

Diskusi kelompok yang dapat membentuk perilaku akademik siswa di SD Negeri Kaduagung.

Diskusi kelompok dalam proses pembelajaran perlu digunakan agar dalam proses pembelajaran dapat lebih menyenangkan dan tidak membosankan, karena hal-hal baru dalam pembelajaran perlu dilakukan bukan hanya ceramah dan tanya jawab namun diskusi kelompok dapat meningkatkan siswa untuk berfikir memecahkan suatu permasalahan secara bersama-sama dengan beberapa pemikiran yang diungkapkan dalam setiap kelompoknya.

Diskusi kelompok adalah suatu percakapan ilmiah beberapa orang yang tergabung dalam suatu kelompok untuk saling bertukar pendapat suatu masalah atau bersama- sama mencari pemecahan mendapatkan jawaban atau kebenaran atas suatu masalah (Subroto, 2002:179).

Dari hasil penelitian yang sudah peneliti lakukan, dalam proses pembelajaran dengan menggunakan metode diskusi kelompok, guru telah berhasil membentuk perilaku akademik yang baik bagi siswa. Hal ini dibuktikan oleh proses pembelajaran yang sudah berlangsung dan dari hasil wawancara yang telah peneliti dan wali kelas $\mathrm{V}$ yaitu ibu Iyus lakukan. Beliau pun menyatakan bahwa dengan menggunakan metode diskusi kelompok dalam proses pembelajaran dapat membentuk serta meningkatkan kualitas perilaku akademik siswa. Dampak dari diskusi kelompok terhadap perilaku akademik dalam pelaksanaan pembelajaran tematik di SD Negeri Kaduagung. proses pembelajaran dengan menggunakan metode diskusi kelompok telah memberikan dampak positif terhadap perilaku akademik siswa.

Hal ini dapat dibuktikan dengan adanya siswa yang sebelum menggunakan metode diskusi kelompok dalam proses pembelajarannya masih malu dan ragu dalam menyampaikan pendapat atau ide pemikirannya dan setelah menggunakan metode diskusi kelompok dalam proses pembelajarannya siswa tersebut menjadi berani dalam mengungkapkan pendapat atu ide pemikirannya tanpa ragu dan hal ini menjadi sebuah kebiasaan yang dilakukan dalam proses pembelajaran, serta guru telah melatih kesiapan atau mental siswa melalui metode diskusi kelompok yang dapat meningkatkan perilaku akademik siswa jauh lebih baik lagi. Dibuktikan dengan hasil wawancara peneliti dan ibu wali kelas $V$ yaitu ibu Iyus lakukan beliau pun menyadari bahwa diskusi kelompok tersebut dapat memberikan dampak positif serta angket penilaian teman sebangku dan angket penilaian teman sekelompok yang dapat menilai perilaku akademik masingmasing temannya.

Dampak dari pembelajaran tanpa menggunakan metode diskusi kelompok terhadap perilaku akademik di SD Negeri Kaduagung. proses pembelajaran tanpa menggunakan metode diskusi kelompok telah memberikan dampak positif terhadap perilaku akademik siswa. Hal ini dapat dibuktikan dengan adanya siswa yang mengajukan pertanyaan kepada guru 


\section{Jurnal Lensa Pendas, Vol. 5 Nomor 1 Tahun 2020, HIm 41 - 47}

Ade Maharani ${ }^{1}$, Dede Darkam ${ }^{2}$

mengenai materi yang sudah guru jelaskan, terdapat pula siswa yang menjawab pertanyaan yang sudah temannya ajukan kepada guru, terdapat siswa yang berdiskusi dengan teman sebangku mengenai soal yang telah diberikan oleh guru.

\section{SIMPULAN}

kesimpulan dari hasil penelitian didapat bahwa perilaku akademik siswa selama proses pembelajaran diskusi kelompok melalui teknik wawancara dengan ibu wali kelas $\mathrm{V}$ dan perwakilan dari siswa kelas $\mathrm{V}$, serta observasi langsung ke lapangan dapat disimpulkan bahwa perilaku akademik siswa selama proses pembelajaran diskusi kelompk dikategorikan cukup baik. Bukan hanya pada proses diskusi kelompok saja, pada proses pembelajaran tanpa menggunakan metode diskusi kelompok pun perilaku akademik yang ditunjukan oleh siswa dikatakan cukup baik. Selanjutmya siskusi kelompok dalam proses pembelajaran di kelas $\mathrm{V}$, berdasarkan hasil wawancara dengan ibu wali kelas $\mathrm{V}$ dan perwakilan dari siswa kelas V serta hasil observasi langsung ke lapangan terbukti bahwa guru telah berhasil membentuk perilaku akademik siswa dengan cukup baik dengan menggunakan metode diskusi kelompok dalam proses pembelajaran. Kemudian dampak dari diskusi kelompok terhadap perilaku akademik dalam pelaksanaan pembelajaran tematik di SD Negeri Kaduagung ini menurut hasil wawancara peneliti dengan ibu wali kelas serta observasi langsung ke lapangan hal ini membuktikan bahwa terdapat dampak yang positif dari pelaksanaan pembelajaran diskusi kelompok terhadap perilaku akademik siswa. Bukan hanya pada diskusi kelompok, pada proses pembelajaran tanpa menggunakan metode diskusi kelompok pun sudah memberikan dampak yang positif bagi perilaku akademik siswa kelas V.

\section{DAFTAR PUSTAKA}

Baharudin. 2009. Pendidikan \& Psikologi Perkembangan. Jakarta: Ar. Ruzz Media.

S Tatang. 2012. Ilmu Pendidikan. Bandung: CV Pustaka Setia.

Sa'ud Udian Syaefudin dan Makmun Arbin Syamsuddin. 2014. Perencanaan Pendidikan. Bandung: PT Remaja Rosdakarya Offset. 2011. Manajemen Kelas Untuk Guru Sekolah Dasar. Jakarta: Kencana.

Sudjana, Nana. 2013. Dasar-dasar Proses Belajar Mengajar. Bandung: Sinar Baru Algensindo

Sugiyono. 2017. Metode Penelitian Pendidikan Pendekatan Kuantitatif, Kualitatif, dan $R \& D$. Bandung: ALFABETA 